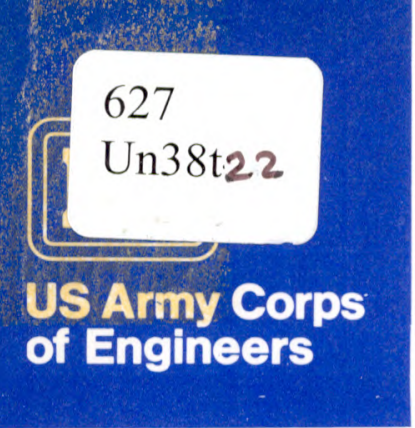

\title{
THE TMA SHALLOW-WATER SPECTRUM DESCRIPTION AND APPLICATIONS
}

by

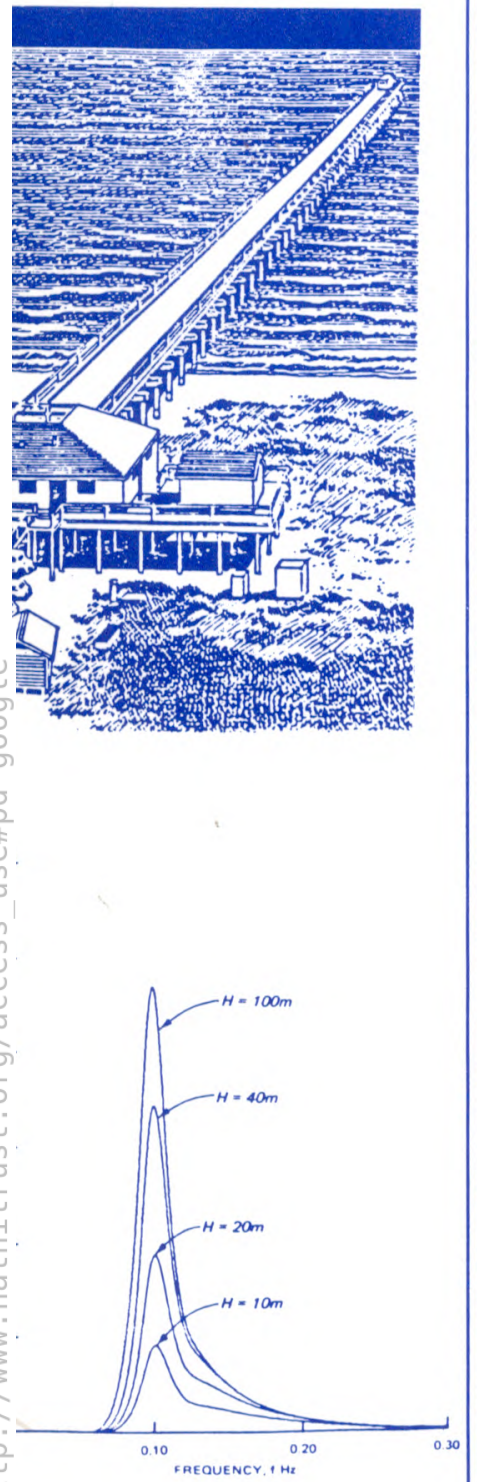

Steven A. Hughes

Coastal Engineering Research Center

DEPARTMENT OF THE ARMY

Waterways Experiment Station, Corps of Engineers PO Box 631, Vicksburg, Mississippi 39180-0631

University of IIIInols Metz Reference Room

B106 NCin

208 N. Romine strest Urbana, IIIinois 61801

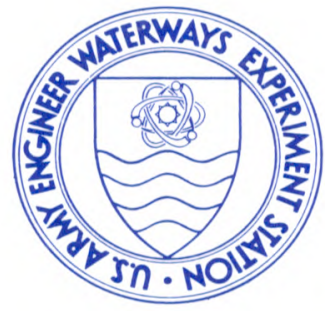

December 1984

Final Report

Approved For Public Release; Distribution Unlimited

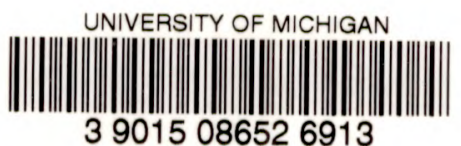

Prepared for DEPARTMENT OF THE ARMY US Army Corps of Engineers Washington, DC 20314-1000

Under Civil Works Research Work Unit 31592 